\title{
Urdimento
}

Revista de Estudos em Artes Cênicas E-ISSN: 2358.6958

\section{Notas sobre a peça Acima de tudo: sociologia e filosofia como bases para a criação teatral}

\author{
Ernesto Gomes Valença
}

\section{Para citar este artigo:}

VALENÇA, Ernesto Gomes. Notas sobre a peça Acima de tudo: sociologia e filosofia como bases para a criação teatral. Urdimento, Florianópolis, v. 3, n. 39, nov./dez. 2020.

DOI: http:/dx.doi.org/10.5965/14145731033920200206

Este artigo passou pelo Plagiarism Detection Software | iThenticate 
Notas sobre a peça Acima de tudo: sociologia e filosofia como bases para a criação teatral

Ernesto Gomes Valença ${ }^{1}$

\begin{abstract}
Resumo
O artigo descreve a metodologia utilizada para a criação da peça Acima de tudo - Teatro antifascista, enfatizando o modo como a dramaturgia e a encenação articularam as bases teóricas estudadas. O neofascismo foi abordado a partir de fontes filosóficas e sociológicas que permitiram estabelecer paralelos entre o período da Alemanha nazista e o Brasil atual, sendo o mais evidente a mobilização, para ideias totalitárias, do sentimento da solidão em meio à multidão. O celular foi tomado como símbolo dessa solidão massificada hiper conectada que gerou o fascismo no Brasil e empregado na encenação tanto como objeto de cena quanto como inspiração para todo o espetáculo.
\end{abstract}

Palavras-chave: Teatro antifascista. Teatro político. Dramaturgia. Teatro e sociologia. Teatro e filosofia.

Notes on the play Acima de tudo: sociology and philosophy as bases for theatrical creation

\begin{abstract}
The article describes the methodology used to create the play Acima de tudo - anti-fascist theater, emphasizing the way in which dramaturgy and staging articulated the theoretical bases studied. Neofascism was approached from philosophical and sociological sources that made it possible to establish parallels between the period of Nazi Germany and Brazil today, the most evident being the mobilization, for totalitarian ideas, of the feeling of loneliness among the crowd. The cell phone was taken as a symbol of this massively hyperconnected loneliness that generated fascism in Brazil and used in the staging both as an object of the scene and as inspiration for the entire spectacle.
\end{abstract}

Keywords: Antifascist theater. Political theater. Dramaturgy. Theater and sociology. Theater and philosophy. 
Notas sobre la obra Acima de tudo: la sociología y la filosofía como bases para la creación teatral

\section{Resumen}

El artículo describe la metodología empleada para la creación de la obra Acima de tudo - Teatro antifascista, destacando la forma en que la dramaturgia y la puesta en escena articulan las bases teóricas estudiadas. El neofascismo fue abordado desde fuentes filosóficas y sociológicas que permitieron establecer paralelismos entre el período de la Alemania nazi y el Brasil actual, siendo el más evidente la movilización, por ideas totalitarias, del sentimiento de soledad en la multitud. El teléfono celular fue tomado como símbolo de esta soledad masivamente hiperconectada que generó el fascismo en Brasil y fue utilizado en la puesta en escena como objeto de la escena y como inspiración para todo el espectáculo.

Palabras clave: Teatro antifascista. Teatro político. Dramaturgia. Teatro y sociología. Teatro y filosofía. 
A proposta deste texto é refletir sobre alguns aspectos da peça Acima de tudo. Será esboçado o modo como as diversas fontes filosóficas, sociológicas e políticas, mobilizadas no processo de construção do espetáculo, foram articuladas especificamente na dramaturgia e em alguns aspectos da encenação.

Trata-se de um dos resultados práticos de uma pesquisa acadêmica que busca aproximar a filosofia de Vilém Flusser (1920, Praga - 1991, Praga) ao contexto teatral, que vem sendo desenvolvida no âmbito do Departamento e do Programa de Pós-Graduação em Artes Cênicas da Universidade Federal de Ouro Preto desde 2012. Atualmente, esta investigação se estrutura através do projeto Dimensões do Jogo no Teatro ${ }^{2}$, integrando a linha de pesquisas Processos e Poéticas da Cena Contemporânea do PPGAC/UFOP, sendo também um projeto vinculado ao Grupo de Pesquisa em História, Política e Cena, liderado pelos Profs. Drs. Carina Guimarães Moreira e Berilo Luigi Deiró Nosella, ambos da Universidade Federal de São João Del Rei ${ }^{3}$.

O projeto realizou experimentações dramatúrgicas e de criação de cenas buscando investigar, na prática, a equivalência entre os conceitos de jogo e programação na filosofia de Flusser. Para tanto, dispositivos de áudio - microfones e amplificadores - e aparelhos celulares foram explorados como objetos de cena nas práticas laboratoriais. Outro aspecto do projeto foi o interesse pela discussão de temas candentes da atualidade, consubstanciado numa prática de adotar textos teóricos - políticos, historiográficos, sociológicos e filosóficos - como material para jogo. Esse procedimento desembocou na construção do texto dramatúrgico e na realização do espetáculo Acima de Tudo.

O núcleo de participantes desse processo adotou o nome Teatro de Viés Ideológico, com vistas à apresentação do espetáculo. Caracteriza-se como um

2 Em momentos anteriores, esta investigação se estruturou através de outros Projetos Integrados, nomeadamente o Caixa Preta, coordenado em colaboração com o Prof. Dr. Éden Silva Peretta, e o Teatro do Tumulto, este último ainda em andamento. Ambos tinham como objetivo a criação de um laboratório teatral envolvendo mídias e novas tecnologias. Enquanto o Caixa Preta tinha como foco o diálogo com a expressão corporal e a dança, o Teatro do Tumulto configura-se como uma experiência de teatro político e histórico. Em ambos os processos foi marcante a experimentação com música e equipamentos como câmeras e projetores. Da mesma forma, as bases teóricas nos dois projetos foram compostas essencialmente pelas ideias e conceitos do filósofo Vilém Flusser, de cujos escritos tiramos o nome "Caixa Preta".

3 <dgp.cnpq.br/dgp/espelhogrupo/5893650868206891> 
grupo de teatro universitário, ligado ao projeto de pesquisa em pauta, formado por alunos de licenciatura e bacharelado do curso de graduação em Artes Cênicas da UFOP $^{4}$, sob coordenação do professor Ernesto Valença. Esse foi o grupo responsável pela criação e apresentação de Acima de Tudo.

A peça aborda o neofascismo, estabelecendo paralelos entre o período da Alemanha nazista e o Brasil atual. A principal analogia gira em torno da constatação de que o sentimento da solidão em meio à multidão foi manipulado, em ambas as situações históricas, para a mobilização de milhares de pessoas a favor de ideias totalitárias. O celular foi tomado como símbolo dessa solidão massificada hiper conectada que gerou o fascismo no Brasil e empregado na encenação tanto como objeto de cena quanto como inspiração para todo o espetáculo. Uma das características principais é a de ser uma peça de fragmentos, contando com cenas muito diferentes entre si em termos estéticos e que sintetizam o amálgama de temas que embasaram a montagem. Não há uma trama central a ser seguida, mas uma série de esquetes significativas em si.

O processo de construção da encenação ocupou o período de agosto de 2018 a junho de 2019, sendo a data da estreia 29/06/19, na cidade de Ouro Preto. Todas as apresentações ocorreram em ambiente universitário, em sala de apresentações adaptada dentro do próprio Departamento de Artes, o público sendo composto principalmente de estudantes de diversos cursos, mas sempre com a presença de pessoas da comunidade e do público de teatro em geral da cidade. Além da encenação, o processo também resultou na escrita de uma dramaturgia publicada em 2020, com o título Acima de tudo - Teatro antifascista, de onde foram tiradas as citações utilizadas neste texto.

\section{A escolha do tema}

Diferentemente de outros processos teatrais, que partem dos desejos, anseios ou percepções de cada um dos participantes, em nosso projeto de 
pesquisa foi acordado com o núcleo de integrantes, desde o início, que os temas a serem abordados pelo espetáculo deveriam surgir de uma leitura mais objetiva da realidade política imediata ou em perspectiva. É certamente um processo de inspiração brechtiana que já vínhamos experimentando em outras ocasiões e que envolve a realização de uma série de discussões, por vezes com participações de convidados de fora do grupo, em que se busca identificar questões candentes ao momento político por que passa o Brasil. Por ocasião de Acima de tudo, o processo durou cerca de seis meses, abarcando o final de 2018 e início de 2019.

Por meio dessas discussões, constatamos que um dos temas mais insistentes em diversos meios de comunicação, artigos e livros lançados nos últimos anos era a leitura de que o Brasil passava por um momento extemporâneo de ascensão do fascismo ${ }^{5}$. O crescimento de governos ultradireitistas, considerados por muitos como fascistas, nesse mesmo período, não se restringiu ao Brasil, como nos exemplos da Turquia (Recep Tayyip Erdoğan), Hungria (Viktor Orbán), Filipinas (Rodrigo "Digong" Roa Duterte) e EUA (Donald Trump). No entanto, a proximidade do tema foi importante como estratégia para a criação do espetáculo: nos interessava como poderíamos responder teatralmente a uma vivência efetiva de ascensão do fascismo, como isso interferia no nosso dia a dia, como afetava nossas convivências, sentimentos e perspectivas.

Iniciamos, então, uma série de estudos sobre autores que abordaram o fascismo ao longo da história, com a intenção de utilizar seus escritos como fonte para a construção da dramaturgia e como motivadores de jogos de criação teatral. Além de levantar os elementos que definiram o fascismo em suas manifestações anteriores, o desafio que nos colocamos foi identificar - às vezes por contraste, às vezes por semelhança - as particularidades do fascismo atual. Dessa forma,

${ }^{5}$ Chegamos a levantar mais de vinte livros e artigos sobre o assunto, lançados em período recente em diversos meios. Como amostra, algumas das que ficaram mais conhecidas são:

Vladimir Safatle. O que é fascismo? Disponível em https://revistacult.uol.com.br/home/o-que-e-fascismo/. Publicado em: 22 out. 2018. Acesso em: 04 fev. 2019.

Marcia Tiburi. Como conversar com um fascista. Rio de Janeiro: Editora Record, 2015.

Extra/Globo. Em São Paulo, Roger Waters chama Bolsonaro de neofascista e cita 'Ele não'. Disponível em https://extra.globo.com/noticias/brasil/em-sao-paulo-roger-waters-chama-bolsonaro-de-neofascista-citaele-nao-23144683.html. Publicado em: 10 out. 2018. Acesso em: 22 nov. 2018

Carta capital. A ascensão do fascismo. Disponível em https://www.cartacapital.com.br/politica/a-ascensaodo-fascismo/. Publicado em: 12 out.2018. Acesso em: 11 fev. 2019 
tratamos o material de estudo sempre em perspectiva com a atualidade, de forma a traçar o perfil que o fascismo assume nos dias de hoje.

\section{A relação do tema com a pesquisa sobre Vilém Flusser}

Os textos de Vilém Flusser há muito já faziam parte das leituras no projeto de pesquisa e, mesmo não sendo um de seus assuntos principais, o fascismo também foi abordado por ele, especialmente em relação a uma de suas noções mais centrais: a pós-história. Segundo o filósofo, a sociedade atual, que ele chama de pós-histórica, é caracterizada pelo domínio de aparelhos gigantescos, que funcionam de modo automático por meio de programas, dentro dos quais os seres humanos operam como funcionários. Aparelho, automatismo, programa e funcionário são conceitos desenvolvidos por Flusser em vários textos.

É muito significativo que no livro Pós-História: vinte instantâneos e um modo de usar, de autoria de Flusser, logo em seu primeiro instantâneo, o nazismo seja apontado como um evento que "esvaziou o chão em que pisamos" (Flusser, 2011, p. 20), e que leva o mundo a entrar em nova fase, pós-histórica, cuja a marca é o funcionamento automático por meio de aparelhos programados. Citando especificamente o campo de extermínio de Auschwitz, diz Flusser (2011, p. 22, grifo do autor) que:

o inaudito em Auschwitz não é o assassinato em massa, não é o crime. É a reificação derradeira de pessoas em objetos informes, em cinza. A tendência ocidental rumo à objetivação foi finalmente realizada, e o foi em forma de aparelho. Os SS eram funcionários de um aparelho de extermínio, e suas vítimas funcionaram em função do seu próprio aniquilamento. O programa do campo de extermínio, uma vez posto em funcionamento, se foi desenvolvendo de maneira automática, autônoma de decisões dos programadores iniciais [...]. Trata-se de aparelho que funciona em situação limite: objetiva até além da morte.

É como se o ato inaugural da pós-história tivesse sido Auschwitz, a primeira e mais decisiva vez em que se concretizou um aparelho de extermínio em escala massificada, operando na forma de um programa automático para produzir morte.

Nesse aparelho automático, a morte das pessoas nunca era tratada em sua 
dimensão humana, mas unicamente como dado, como informação. Esse, um dos atributos do aparelho que caracterizam a Pós-História: a transformação automática de toda dimensão humana em simples informação, em simples dado de programação. Flusser voltaria a abordar o assunto em outros textos, a exemplo de O último juizo: gerações //, sempre associando o nazismo ao funcionamento de um aparelho voltado à programação automática e estúpida da morte.

Dessa forma, o próprio projeto de pesquisa geral - sobre como aproximar a filosofia de Flusser do universo teatral - se coadunou à percepção de que o fascismo era o tema candente da atualidade. Em especial, trouxe aos participantes do processo de criação um guia para abordagem do fascismo atual: seja qual for sua manifestação aparente, ele funciona em forma de aparelho com programação automática. Assim, elementos que compõem o aparelho tal como caracterizado por Flusser - automatismo, presença de funcionários e programação -, delinearam nossas matrizes de interpelação do fascismo contemporâneo.

\section{Aparelho paradigmático}

A partir desse primeiro entendimento derivado da filosofia de Flusser, passamos a realizar uma série de jogos e experimentos teatrais visando encontrar a melhor forma de expressar cenicamente o funcionamento do fascismo como aparelho. Através desse procedimento, chegamos ao celular como um signo de automatismo e programação social, muito representativo do momento atual.

É verdade que o conceito de aparelho de Flusser é mais amplo do que o de um equipamento específico como o celular, assemelhando-se mais a um sistema complexo, em que várias partes se interligam gerando gigantescas cadeias de programações automatizadas. Fábricas, empresas, instâncias governamentais, ramos inteiros da economia e do processo produtivo, ao agirem interconectados, funcionando automaticamente por meio de programas, são, igualmente, aparelhos. Porém, entendemos que nenhum outro equipamento seria capaz de significar tão bem a profunda conexão que o ser humano estabelece com o aparelho na atualidade como o celular, usado no dia-a-dia e quase que integrado 
ao nosso corpo. É notória a centralidade que o aparelho celular ocupa em diversas instâncias do mundo contemporâneo, das relações pessoais às transações econômicas.

O celular nos pareceu uma escolha simples e óbvia como signo de aparelho e, ao mesmo tempo, muito potente cenicamente. O seu funcionamento automático por meio de programas (os extremamente difundidos apps) já é amplamente reconhecido; e a sua utilização generalizada aproxima o espectador do universo que seria discutido na peça. Assim, nos jogos e laboratórios realizados em sala de ensaio, buscamos explorar cenicamente essas duas dimensões interligadas do uso dos celulares: os programas automáticos internos e sua utilização generalizada.

Ademais, o celular não somente é essa espécie de aparelho paradigmático da nossa contemporaneidade, como também teve importância fundamental na proliferação do fascismo nos últimos anos, ao menos no Brasil. Basta constatar que foram os programas de celulares, em sua grande parte, os principais meios de articulação de amplas redes de contato em todo o país e que resultaram em agressivas manifestações massivas, posteriormente desdobradas em campanhas difamatórias, que são os exemplos mais habituais nas discussões sobre o ressurgimento do fascismo no Brasil nos últimos tempos ${ }^{6}$.

Destarte, os celulares fizeram parte do processo de criação do espetáculo

\footnotetext{
${ }^{6}$ Pesquisas do IBOPE dão conta de que, a partir de 2013, cerca de 70\% de participantes de passeatas de rua ficaram sabendo das manifestações por meio virtual (IBOPE, 2013). Além disso, desde 2013 trabalhos acadêmicos têm estudado a crescente importância da internet para os movimentos políticos recentes, apontando a mutação das pautas reivindicatórias, cada vez mais abertamente retrógradas e antidemocráticas, quando não flertando com o fascismo explícito. Ver, entre outros exemplos:

Rafael Evangelista; Fernanda Bruno. 2019. WhatsApp and political instability in Brazil: targeted messages and political radicalisation. Internet Policy Review, 8(4). DOI: 10.14763/2019.4.1434. Disponível em: http://policyreview.info/articles/analysis/whatsapp-and-political-instability-brazil-targeted-messagesandpolitical. Acesso em: 10 fev. 2020
}

Frank Marcon. Agências estetizadas, geração digital, ativismos e protestos no Brasil. Ponto Urbe (Online), 23 , 2018. Revista do Núcleo de Antropologia Urbana - Universidade de São Paulo. Publicado online no dia 17 dezembro de 2018. Disponível em: http://journals.openedition.org/pontourbe/4539; DOI: https://doi.org/10.4000/pontourbe.4539. Acesso em:_04 abr. 20.

Ver também o Projeto de Pesquisa Eleições Sem Fake, iniciativa do Departamento de Ciência da Computação da Universidade Federal de Minas Gerais - DCC/UFMG, que tem se tornado uma referência no que diz respeito ao estudo da interferência da internet e de aplicativos de mensagens nos rumos políticos do país nos últimos anos. Sítio: https://www.eleicoes-sem-fake.dcc.ufmg.br/ 
Acima de tudo de pelo menos duas maneiras diferentes: (1) manipulados diretamente em cena como objetos diante dos espectadores e (2) como uma referência mais especulativa, representando profundas transformações nas relações pessoais e na percepção da realidade; consequências sociais advindas da hiper conectividade.

\section{Transitando entre aparelhos}

Uma característica da encenação foi que a transição entre cenas ocorria em frente ao público, de modo não velado. Assim, tornou-se um desafio para toda a equipe realizar a reorganização do espaço de modo a se integrar à totalidade do espetáculo, ainda que em forma de rompimento com a dinâmica que vinha se apresentando. Esse desafio foi resolvido de maneiras diferentes para cada transição, mas a solução criada pelos atores para o início da Cena 7 foi especialmente convergente com a discussão que vínhamos fazendo acerca da centralidade do celular na sociedade atual, além de exemplificar seu uso direto como objeto de cena.

A proposta de transição partiu da dupla de atores que atuava na cena, na forma de um jogo que foi prontamente aceito pela equipe. O roteiro do jogo se estruturava assim: parte dos atores pegava seus celulares e se misturava ao público, sentando lado a lado com os espectadores na plateia, enquanto outra parte, também munida de celulares, permanecia na área de atuação realizando as mudanças de cena. Os atores junto ao público enviavam mensagens de áudio pelo aplicativo WhatsApp aos atores em cena, orientando como deveriam realizar a transição, como ordenarem os objetos, lembrando de tirar ou colocar um microfone ou uma cadeira. Esses áudios eram improvisados e jogavam com os acontecimentos de cada dia: por vezes, podia-se ouvir mensagens como "cuidado com o fio do microfone"; "tem um copo que ficou em cena"; "vamos apressar, porque o público está perdendo a atenção!”; e outras.

O uso explícito dos celulares e de um aplicativo de mensagens instantâneas instaurava um jogo espaço-temporal manifesto: era evidente que os atores no 
espaço de atuação podiam ouvir os atores da plateia "ao vivo", sem a mediação dos celulares; no entanto, os atores na área de atuação só tomavam providências quanto à organização da cena depois de ouvirem as mensagens nos celulares em suas mãos, que eram reproduzidas no modo viva-voz e, portanto, audíveis também para o público. Os espectadores percebiam essa dessincronia na comunicação, ouvindo a emissão ao seu lado e, momentos depois, a chegada da mensagem na área de atuação. Ocorria uma espécie de ruptura comunicacional, no espaço e tempo de uma comunicação que poderia ser obviamente imediata, mas que era arbitrária e artificialmente mediatizada.

De certo modo, o jogo evidenciava a perda da capacidade de comunicação humana direta, imediata, que resulta precisamente do excesso de equipamentos de comunicação, de mídias, na sociedade contemporânea, denunciando nossa adesão condescendente aos aparelhos. O pesquisador e crítico Clóvis Domingos, em um texto sobre o espetáculo publicado em site especializado em críticas teatrais, enfatiza precisamente estes aspectos dessa cena:

Quando os atuantes se misturam à plateia e com seus aparelhos celulares enviam mensagens pelo WhatsApp, numa tentativa de organizar a próxima cena, essa invasão tecnológica tão discreta e minúscula, aponta para sua eficácia em meio à nossa carne viva no tecido social, e nesta operação metalinguística, denuncia sua infiltração perversa em nossas possibilidades de comunicação mais humanizada, mais dialógica, mais corpo a corpo. Essa "direção" acontecendo tanto no teatro como em nossa realidade mesmo. (Domingos, 2019, s/p).

De outro modo, essa cena também ativava uma espécie de jogo de percepção oscilante, que alternava constantemente a atenção do público entre o sentido das mensagens - enunciados que orientavam a reorganização do espaço de cena - e a própria estrutura comunicacional, com todas as etapas da comunicação explicitamente demonstradas frente ao espectador. Ao colocar em perspectiva os atores - corporalmente presentes e emitindo mensagens organicamente com sua voz - e o áudio do aplicativo - captado digitalmente e transmitido virtualmente , a cena acabava enfatizando o próprio processo de produção da comunicação; acabava ressaltando o meio sonoro, automático e aparelhístico dos celulares. É a 
própria performance tecnológica dos celulares que era colocada em evidência e que capturava a atenção dos espectadores.

Dessa forma, a dinâmica do jogo foi capaz de ultrapassar uma abordagem limitada ao assunto tratado nesse trecho da peça (que afinal era banal: a necessidade de reorganização do espaço e dos objetos para a próxima cena), trazendo para primeiro plano o processo de fabricação, de feitura, de produção da própria comunicação contemporânea, com tudo o que ela tem de absurdo e insensato.

\section{Massas de solitários, ajuntamentos de solidões}

Os celulares ainda foram o ponto de partida para aquela que é, provavelmente, a reflexão central da peça Acima de tudo: o sentimento da solidão é o item que serviu de vínculo entre uma sociedade hiper conectada e o ressurgimento do fascismo. A sensação de que esses três elementos - hiper conectividade, solidão e neofascismo - estavam profundamente ligados perpassou todo o processo de criação e serviu de inspiração para praticamente todas as cenas do espetáculo.

De início, a relação entre eles não nos parecia evidente, se apresentando mais como uma "intuição amorfa", que foi, pouco a pouco, sendo sustentada pelos estudos que passamos a fazer, acompanhados de jogos e laboratórios de criação. As pesquisas realizadas no processo sobre esse assunto podem ser divididas em dois tópicos: a apropriação do sentimento de solidão pelo fascismo em outros períodos e a propagação da solidão em nosso momento atual através dos aparelhos celulares.

Essa espécie de ideia mestra da peça pode ser resumida da seguinte forma: o fascismo nasce da solidão em massa. Obviamente, nem toda solidão gera fascismo, assim como seria um equívoco tremendo atribuir a um único sentimento a responsabilidade pelo surgimento de um movimento totalitário massivo. No

7 Brook, 1995. 
entanto, o fato é que essa peculiar associação entre solidão massificada e fascismo já foi notada por eminentes pesquisadores.

Os intelectuais ligados a Escola de Frankfurt são o exemplo mais evidente. No âmbito dos estudos sobre a indústria cultural, o próprio conceito de massificação, em permanente dialética com a noção de individuação, foi desenvolvido levando em consideração precisamente a ascensão do nazismo. Herbert Marcuse, por exemplo, apontava que os movimentos totalitários promoviam o ajuntamento de indivíduos em massa exatamente através da manipulação do sentimento de isolamento:

O Terceiro Reich é, na verdade, um "Estado das massas" no qual todos os interesses e forças individuais estão submersos em uma massa emocional humana, habilidosamente manipulada pelo regime [...]. A coordenação dos indivíduos em uma multidão intensificou, em vez de abolir, sua atomização e o isolamento entre eles [...]. A ênfase no indivíduo, que permeia suas proclamações ideológicas, tem sua contrapartida na organização nacional-socialista das massas, guiadas pelo princípio da atomização e do isolamento [...]. Esta atomização e isolamento fornece o terreno seguro no qual as forças e faculdades do indivíduo podem servir ao regime. (Marcuse, 1999, p.122).

No entanto, provavelmente quem melhor e mais diretamente abordou a associação entre fascismo e solidão foi a cientista política Hannah Arendt, cuja obra Origens do Totalitarismo (1989) foi uma das principais referências pesquisadas durante a montagem do espetáculo. Assim como os pesquisadores da Escola de Frankfurt, Arendt também entendia a solidão como um dos resultados da massificação da sociedade, habilmente manipulada pelo fascismo no apelo a multidões de indivíduos atomizados e isolados, cujo único princípio unificador é o desejo de expressar seu desalento, sua desesperança e seu desprezo pela política tradicional.

Arendt (1989) considerava a capacidade de mobilizar o sentimento de solidão, com o intuito de forjar uma unidade política, tão importante para caracterizar o fascismo, que a última parte de seu monumental estudo, uma espécie de conclusão do livro, é dedicada quase que exclusivamente a esse aspecto. A autora propõe que é precisamente por mobilizar um sentimento tão profundo, íntimo e 
primordial da experiência humana comum, como é o caso da solidão, que o fascismo consegue ser caracterizado como um regime totalitário, ou seja, um regime que atinge a totalidade da vivência, da existência humana; um regime que "baseia-se na solidão, na experiência de não pertencer ao mundo, que é uma das mais radicais e desesperadas experiências que o homem pode ter." (Arendt, 1989, p. 527).

A cientista política aponta, ainda, que uma sociedade que produz de forma massiva a solidão, como vivência individual e cotidiana, é uma sociedade potencialmente propícia ao advento do fascismo, afirmando que "o que prepara os homens para o domínio totalitário no mundo não-totalitário é o fato de que a solidão [...] passou a ser, em nosso século, a experiência diária de massas cada vez maiores" (Arendt, 1989 p. 530). Sua análise, ao levar em conta o homem-massa da Alemanha da década de 1930/40, vivendo em cidades superpovoadas em que a individualidade se dissipa, foi uma das mais precisas em estabelecer a relação entre massificação, solidão e totalitarismo.

A solidão, o fundamento para o terror, a essência do governo totalitário, e, para a ideologia ou a lógica, a preparação de seus carrascos e vítimas, tem íntima ligação com o desarraigamento e a superfluidade que atormentavam as massas desde o começo da Revolução Industrial. (Arendt, 1989, p. 528).

Como se sabe, a vivência diária da solidão não é uma exclusividade da época de Arendt. Na verdade, o tópico da solidão surgiu em nosso processo por ser uma experiência que o próprio coletivo de criação do espetáculo já reconhecia no seu cotidiano. O grupo identificava o celular como o aparelho mais presente na vida de cada um, entendendo que o acesso facilitado à internet que ele viabiliza cria uma espécie de dependência constante por novidades, novas informações por vezes absolutamente banais que, ao final, não acrescentam nada ao conhecimento ou à formação da personalidade. Essa sensação de incompletude era associada pelo grupo à noção de solidão.

Buscando apreender essa sensação, o coletivo de criação se aproximou dos textos do sociólogo Zygmunt Bauman, a partir do tópico da liquidez dos 
relacionamentos, e do filósofo Byung-Chul Han, com seu diagnóstico de um corpo social depressivo e ansioso em razão de um excesso de positividade. Seus escritos são referência para o debate sobre a intensificação de um sentimento de profunda solidão e desamparo na sociedade hiper conectada da atualidade. Paradoxalmente, quanto mais se ampliam as possibilidades de contato com outras pessoas, tanto mais nos sentimos sós, desprotegidos e em isolamento. A sociedade contemporânea dispõe de aparelhos que, por proporcionarem o acesso massivo e constante à informação e ao contato virtual entre as pessoas, estabelecem novos contornos ou novas formas de lidar com o sentimento de isolamento. Para Zygmunt Bauman, um dos fascínios da internet reside na ambiguidade de ser tanto superação quanto aprofundamento da solidão:

O advento da internet permitiu esquecer ou encobrir o vazio, e, portanto, reduzir seu efeito deletério; pelo menos a dor podia ser aliviada. Contudo, a companhia que tantas vezes faltava e cuja ausência era cada vez mais sentida parecia retornar nas telas eletrônicas, substituindo as portas de madeira, numa reencarnação analógica ou digital, embora sempre virtual. (Bauman, 2011, p.15).

Por seu turno, o filósofo Byung-Chul Han constata que a solidão está na base da depressão, da ansiedade, da síndrome de hiperatividade e de burnout, que se tornaram as doenças por excelência de sociedade atual, obsessiva por hiper conectividade e por hiper desempenho do sujeito. Para Han, "o cansaço da sociedade do desempenho é um cansaço solitário, que atua individualizando e isolando" (Han, 2017, p.71), já que o sujeito contemporâneo, autocentrado e narcisista, é "totalmente incapaz de sair de si, estar lá fora, de confiar no outro, no mundo, fica se remoendo, o que paradoxalmente acaba levando a autoerosão e ao esvaziamento" (Han, 2017, p. 91). A perda da capacidade de estabelecer relações confiáveis com o outro - que diferencia, para Han, o tipo de solidão atual -, está ainda ligada diretamente ao predomínio da internet como veículo de comunicação:

Também os novos meios de comunicação e as técnicas de comunicação estão destruindo cada vez mais a relação com o outro. O mundo digital é pobre em alteridade e em sua resistência. Nos círculos virtuais, o eu pode mover-se praticamente desprovido do "princípio de realidade", que seria um princípio do outro e da resistência. (Han, 2017, p. 91). 
No período de criação de Acima de tudo, a junção do estudo de Hannah Arendt, sobre a solidão do homem-massa como fundamento do fascismo, com as análises de Zygmunt Bauman e Byung-Chul Han, sobre as novas configurações de solidão num mundo hiper conectado, potencializou uma série de discussões internas ao grupo sobre o fenômeno do neofascismo em nossa sociedade atual. Enriquecida por um processo de jogos e laboratórios teatrais, que permitiu acrescentar à discussão teórica as experiências e impressões próprias dos participantes, essa intuição de profundo vínculo entre hiper conectividade, solidão e neofascismo influenciou todo o espetáculo.

\section{Multidão de solitários que se tocam com a ponta dos dedos}

Duas cenas em particular refletem mais precisamente esse processo de estudos e experimentações: a Cena 3, Massas Solitárias, e a já citada Cena 7, Essas pessoas tocam o mundo através dos dedos, cuja transição fez uso explícito dos celulares. Essas cenas apresentam uma estrutura parecida, o que permite abordálas comparativamente: ambas tratam da relação entre massificação, solidão e fascismo; foram compostas por textos poético-reflexivos, em forma de monólogos segmentados; e derivam de jogos teatrais realizados em sala de ensaio.

O sentimento de isolamento em meio à multidão, de solidão massificada, teve papel central nessas cenas, que buscaram tirar proveito da sua natureza contraditória, paradoxal; uma junção de aspectos conflitantes ou díspares, de onde o fascismo retira potencialidade. Um exemplo de como esse tópico foi abordado se encontra no seguinte trecho, da Cena 3:

Quando nós chegamos, já existiam as imensas cidades catastróficas, gigantes, descomunais, intimidadoras. Fomos separados e abandonados uns dos outros. Átomos na sociedade, átomos sociais espalhados pelos confins das cidades, acotovelando-nos uns nos outros como conhecidos de outras datas. Atomização social e individualização extrema, fragmentos da sociedade atomizada em estrutura competitiva. [...]. E a consequente solidão, solidão, solidão, solidão, solidão, solidão, solidão, solidão, solidão, solidão, solidão, solidão, solidão, solidão, solidão, solidão, [...]. Assim nos tornamos massa! Seres humanos massa seres massa humanos massa. Assim criam-se as massas. Por isso criam-se as 


\section{Urdimento}

massas. As massas foram criadas para nosso ímpeto de consumo ímpeto de grasnar e ímpeto de divertir-se da solidão de fuga da solidão da morte $^{8}$. (Valença, Acima de tudo, 2020, p. 43, 44 e 47).

Figura 1 - Acima de tudo

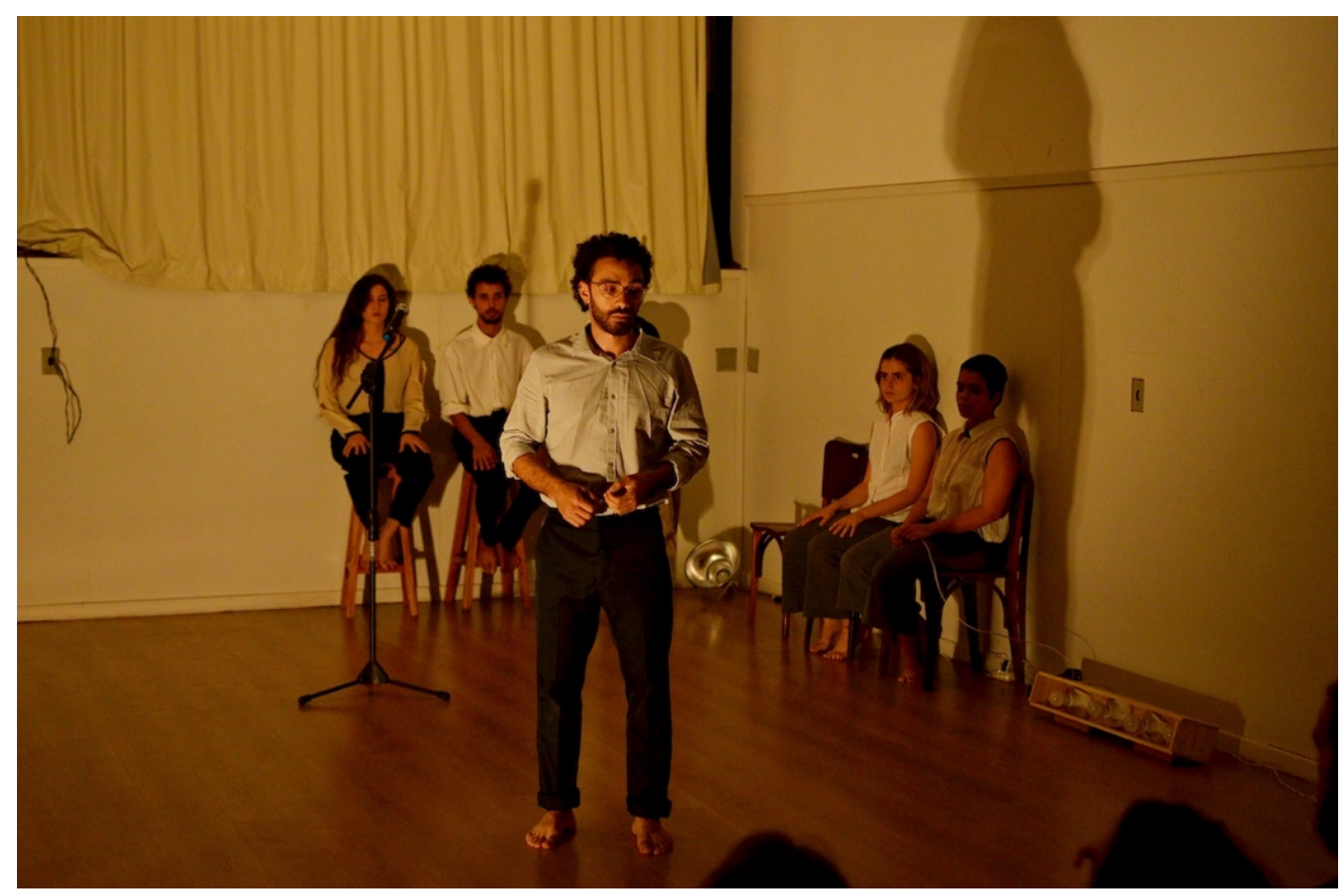

Foto: Gustavo Maia

Por sua vez, a Cena 7 assume um feitio mais incisivo, denunciando o par solidão/massificação como consequência direta do uso ininterrupto dos celulares, como exemplificado na seguinte passagem:

Essas pessoas tocam o mundo através dos dedos. Têm as cabeças baixas mas parecem felizes. Elas não olham para o alto elas não levantam o olhar elas não sabem e não querem saber e sentem orgulho de sua estupidez. Elas estão sozinhas em multidão. Uma multidão de solidões. (Valença, 2020, p. 81).

A referência a multidões que, com o rosto absorvido pelas pequenas telas,

${ }^{8}$ Uma característica da dramaturgia de Acima de tudo é a escassez de vírgulas e pontos finais, em especial nos segmentos que se organizam nesse formato de monólogos justapostos. Mantivemos essa característica na citação dos trechos da dramaturgia, tal como se encontra publicada. 
"não sabem e não querem saber", remete também ao uso dos celulares como uma espécie de meio de entorpecimento, de anestesia em relação ao cotidiano, o que se coaduna plenamente à solidão. Nesse sentido, o celular e a internet tornam-se modos de fuga da realidade, na maior parte das vezes em direção ao consumo de produtos e mercadorias, mas também de ideias, posturas sociais e relações mormente superficiais e supérfluas - "líquidas", na terminologia de Bauman. Na Cena 3, esse aspecto narcótico dos aparelhos foi abordado do seguinte modo:

O objetivo/desejo é esquecer desse contexto insignificante em que nos encontramos - completamente sozinhos e incomunicáveis - esquecer desse mundo em que ocupamos uma cela solitária e em que somos condenados à morte. Consumir grasnar divertir-se consumir grasnar divertir-se consumir grasnar divertir-se consumir grasnar debochadamente divertir-se consumir incontidamente grasnar matraquear pervertidamente divertir-se consumir adquirir descomunalmente grasnar matraquear pervertidamente divertir-se depravadamente divertir-se divertir-se divertir-se divertir-se divertir-se divertir-se rir histericamente até que o ar dos pulmões se esgote até a extinção. (Valença, 2020, p. 45).

No trecho acima, é também mobilizada a noção de "diversão", importante no pensamento de Flusser. Para ele, a diversão é um componente de ocultação da realidade, intrínseco aos meios de comunicação de massa, ao qual temos aderido passiva e intencionalmente: os media nos "divertem", ou seja, nos dispersam, nos desviam, nos divergem, nos desconcentram, nos apartam do universo, nos fazem esquecer, nos desresponsabilizam em relação às coisas do mundo?

A colaboração acrítica com os programas "divertidos" dos aparelhos é abordada na Cena 7 na forma de denúncia de um comportamento subserviente, autômato, dócil e adaptado ao autoritarismo dos aparelhos:

Todos somos colaboradores agora todos colaboramos aceitamos ajudamos a construir e destruir erigir e desmoronar fazer e desfazer. Colaboramos. Colaboramos somos colaboradores nas fábricas nas lojas nas redes viva as redes os laços rápidos e ligeiros e fáceis e desfazíveis

${ }^{9}$ Dadas as dimensões e o foco do presente artigo, não é possível um maior aprofundamento no pensamento de Flusser sobre a comunicação, que é muito mais extenso e complexo do que o apresentado aqui. Especificamente sobre a noção de "diversão" no contexto da comunicação de massas, ver em especial Flusser, 2008 
viva os dedos que são capazes de colaborar! Como animais adestrados e felizes em colaborar e felizes em não manchar a parede em não cagar no tapete em não mijar nos móveis da sala em não tentar trepar com a perna dos convidados em não incomodar em estar adaptado em estar feliz e adaptado feliz por não saber por abrir mão por não ter que decidir. Feliz feliz feliz... como um cachorro adestrado nossos dedos caninos nossos dedos cachorros felizes. As cabeças estão baixas mas elas parecem felizes felizes nas fotos e vídeos e lugares e festas felizes por colaborarem. (Valença, 2020, p. 83 e 84).

Figura 2 - Acima de tudo

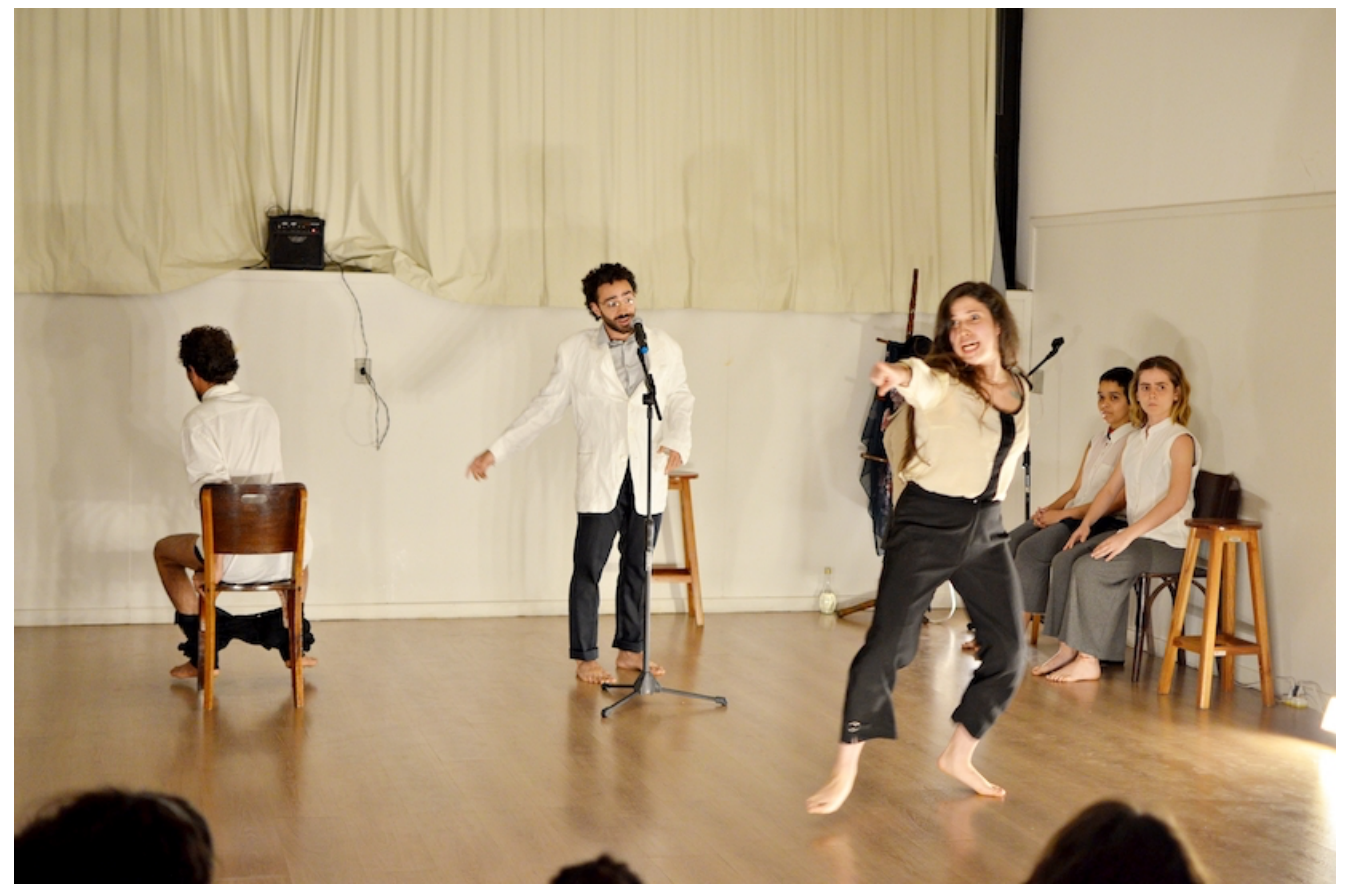

Foto: Gustavo Maia 
Figura 3 - Acima de tudo

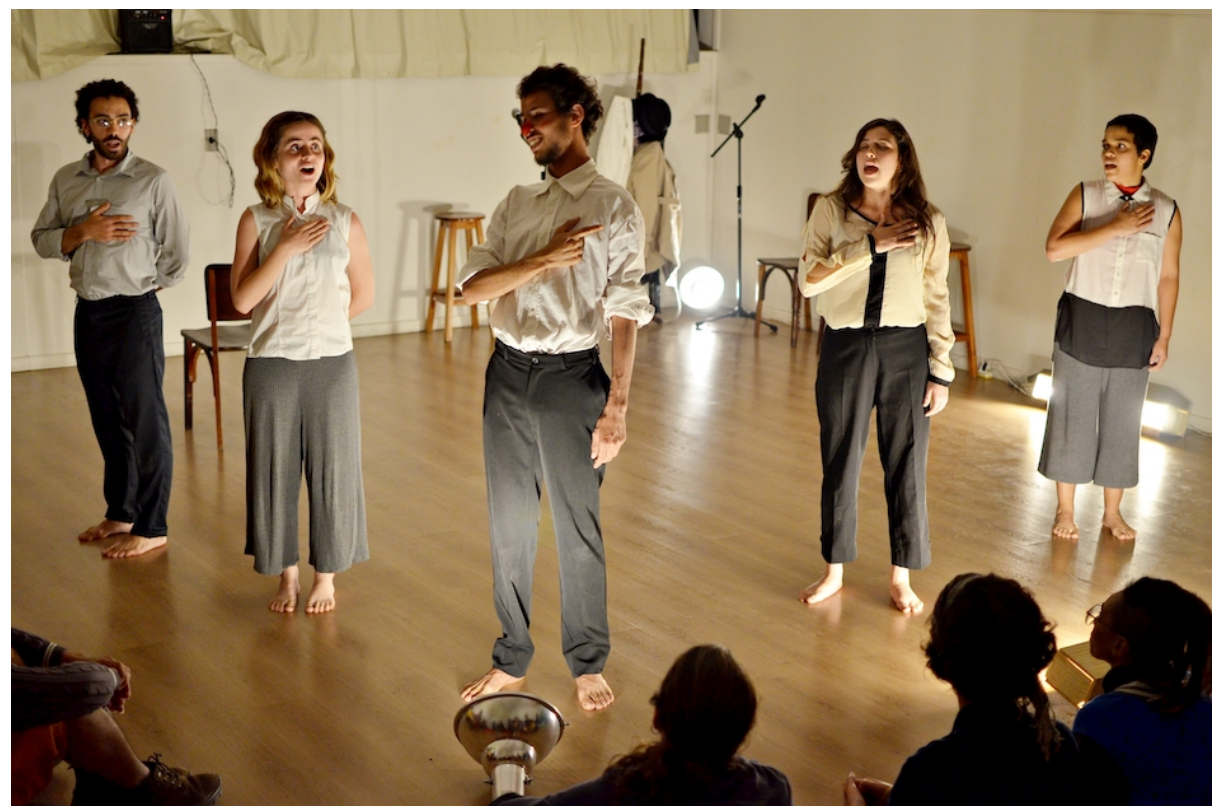

Foto: Gustavo Maia

Porém, a potência maior dessas cenas não está somente em suas dramaturgias, mas na forma como foram encenadas: jogos teatrais que, apesar de organizados em estruturas lúdicas manifestas, deixavam transparecer a impressão de uma motivação oculta para as ações, como se fossem impulsionadas mecanicamente por alguma espécie de força automática impalpável, inacessível e irrefreável. Destarte, a encenação específica dessas cenas atingiu uma forma teatral que corresponde à leitura de Flusser do fascismo, como um aparelho que programa comportamentos automáticos do ser humano.

A encenação da Cena 3 configurava um jogo que remetia diretamente ao título da cena, "Massas solitárias". Enquanto um atuante proferia seu texto em direção ao público em um microfone, todos os outros encostavam os ouvidos no chão ou nas paredes da sala, "buscando ouvir rumores de multidões suicidas que vêm caminhando desde muito, muito longe, no tempo e no espaço" (Valença, 2020, p. 43), conforme descrito na rubrica da cena. Essas ações se revezavam entre os quatro atuantes que, além do mais, propunham variações rítmicas para os deslocamentos e dinâmicas diferenciadas de reação ao texto pronunciado. 
Figura 4 - Acima de tudo

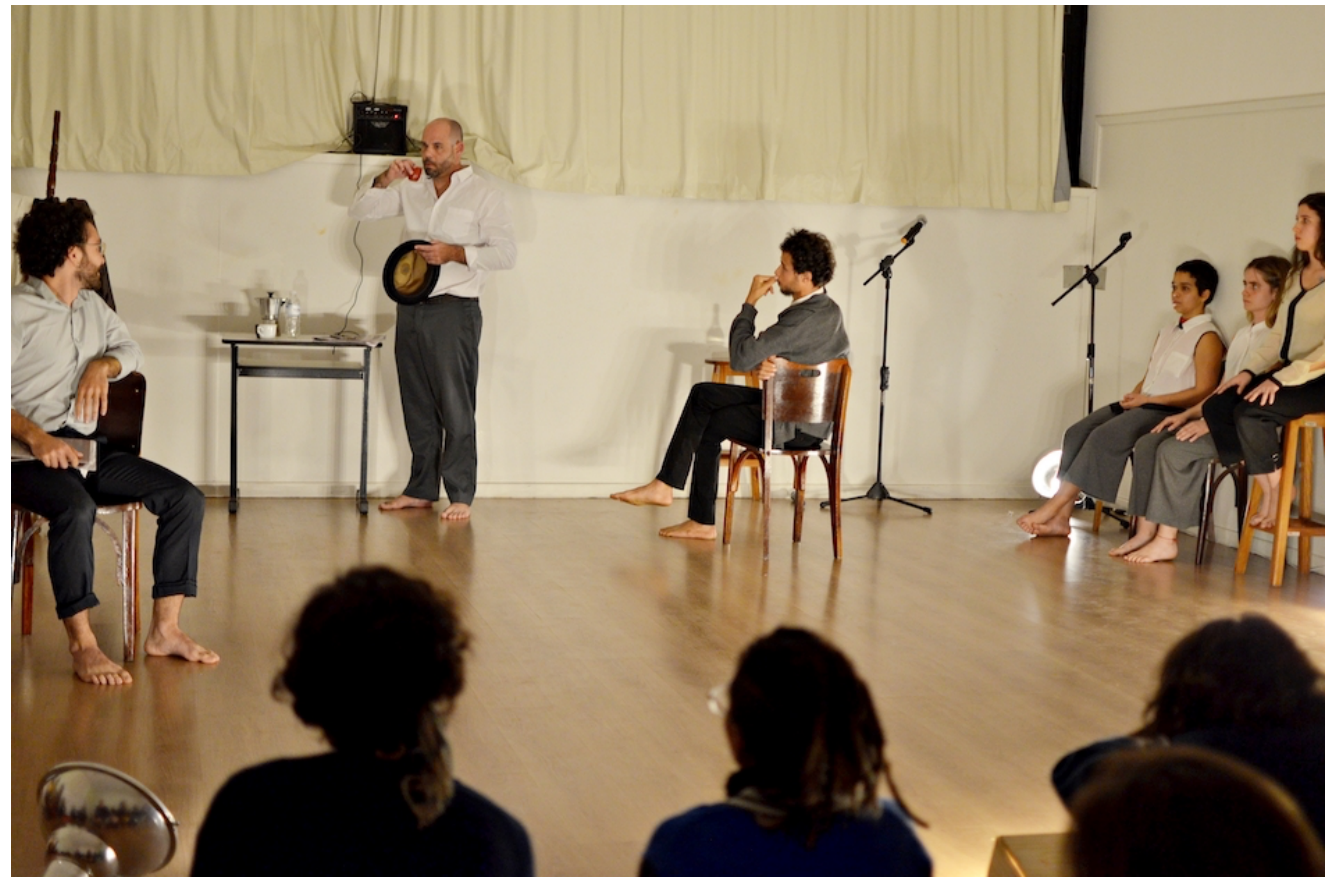

Foto: Gustavo Maia

O jogo era uma referência tanto às "massas solitárias” genéricas de que fala Hanna Arendt em sua análise sobre a gênese do nazismo alemão, quanto às manifestações protofascistas específicas que mobilizaram milhões de brasileiros desde 2014, marcadamente violentas e opressoras, e que desembocaram posteriormente na articulação de uma candidatura à Presidência da República nas eleições de 2018. A repetição de frases como "elas estão chegando", "eu senti a vibração", "elas se aproximam, se aproximam", "agora sim, posso ouvir com força", improvisadas pelos atuantes durante a ação de colocar os ouvidos no chão e nas paredes, remetia a uma espécie de medo sem forma e sem foco, como se a ameaça viesse por todos os lados e não pudesse ser detida, porque não pode ser vista, identificada: ela vem da solidão, da massificação da sociedade, da atomização social. 
Figura 4 - Acima de tudo

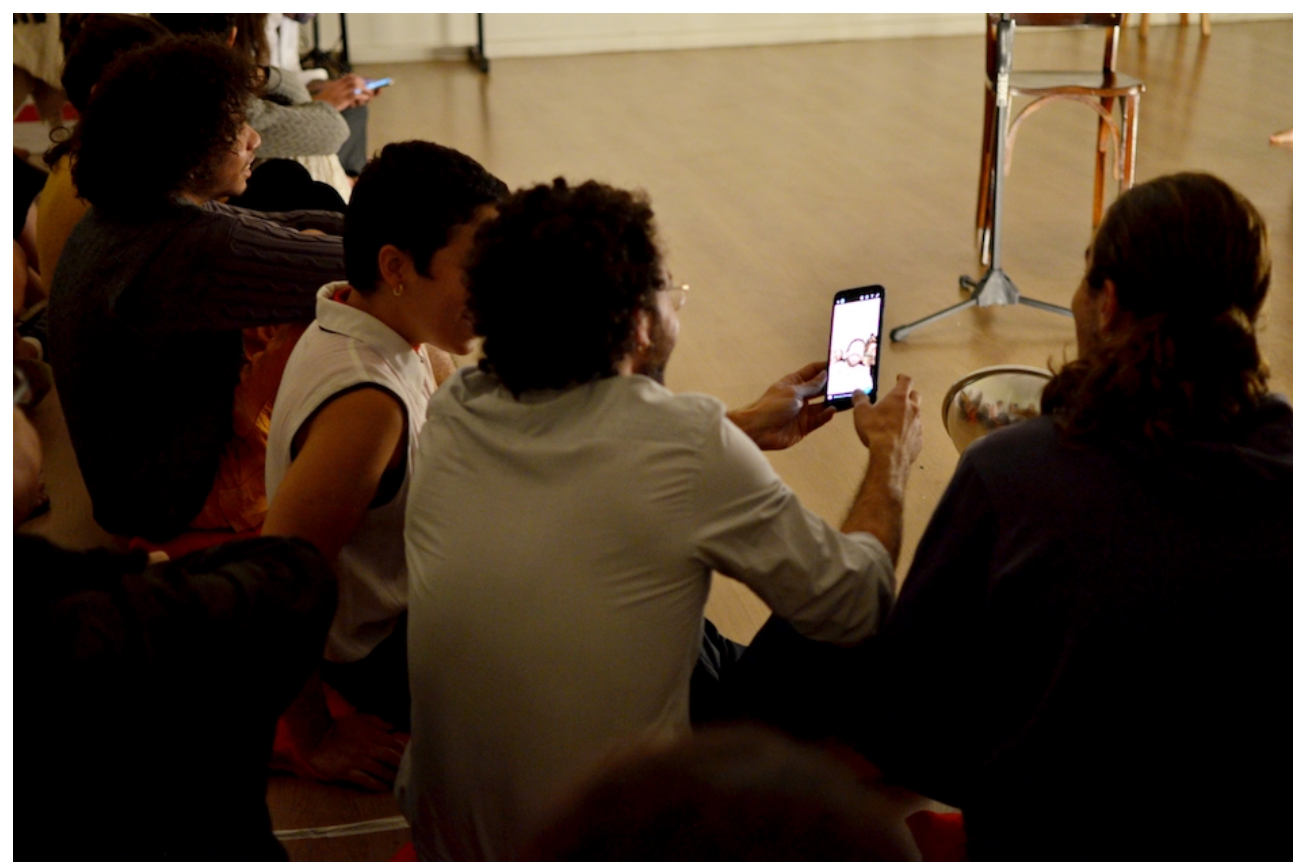

Foto: Gustavo Maia

Por seu turno, a montagem da Cena 7 comportava um jogo muito simples e ao mesmo tempo bastante intenso, proposto pela dupla que assumiu a atuação nesse trecho. Consistia do seguinte roteiro de jogo: a qualquer momento da cena, um dos atuantes poderia se dirigir ao outro e dizer a palavra "morre"; o/a atuante que recebesse essa ordem deveria imediatamente cair no chão e de lá prosseguir a cena, lentamente retomando o ritmo anterior, seja emitindo um texto, seja reestabelecendo a conexão com o outro/outra através do olhar ou de respostas gestuais. Um ponto forte do jogo era o contraste entre a simplicidade das regras e a necessidade de uma presença corporal intensa, já que os atuantes respondiam à ordem de "morre" com quedas bruscas imediatas.

O jogo constituía uma forma de reação ao texto por parte dos atuantes que, mais do que simplesmente enriquecer o ato de fala, remetia a uma sensação de impotência diante de uma situação à qual não se pode esboçar nenhuma resposta, a não ser a reação mecânica de obedecer à ordem de morrer. Apontava igualmente a uma incapacidade de representação do tormento do isolamento, como se não houvessem mais meios comunicativos que pudessem dar a conhecer o peso, a 
fragilidade e o terror da solidão - uma vez que, neste jogo, todas as vezes que alguém desejava expressar seu desespero, o outro respondia com: "morre!", interrompendo esse procedimento. Os meios de expressão da solidão foram tomados pelo fascismo, que projeta seu grito de morte, sempre que se pretende dar vazão a esse sentimento. Talvez por isso, em conversas informais posteriores às apresentações, era sempre a cena lembrada pelos espectadores como a mais forte do espetáculo; e a que mais mobilizou a equipe de realizadores nos momentos de ensaio.

Figura 4 - Acima de tudo

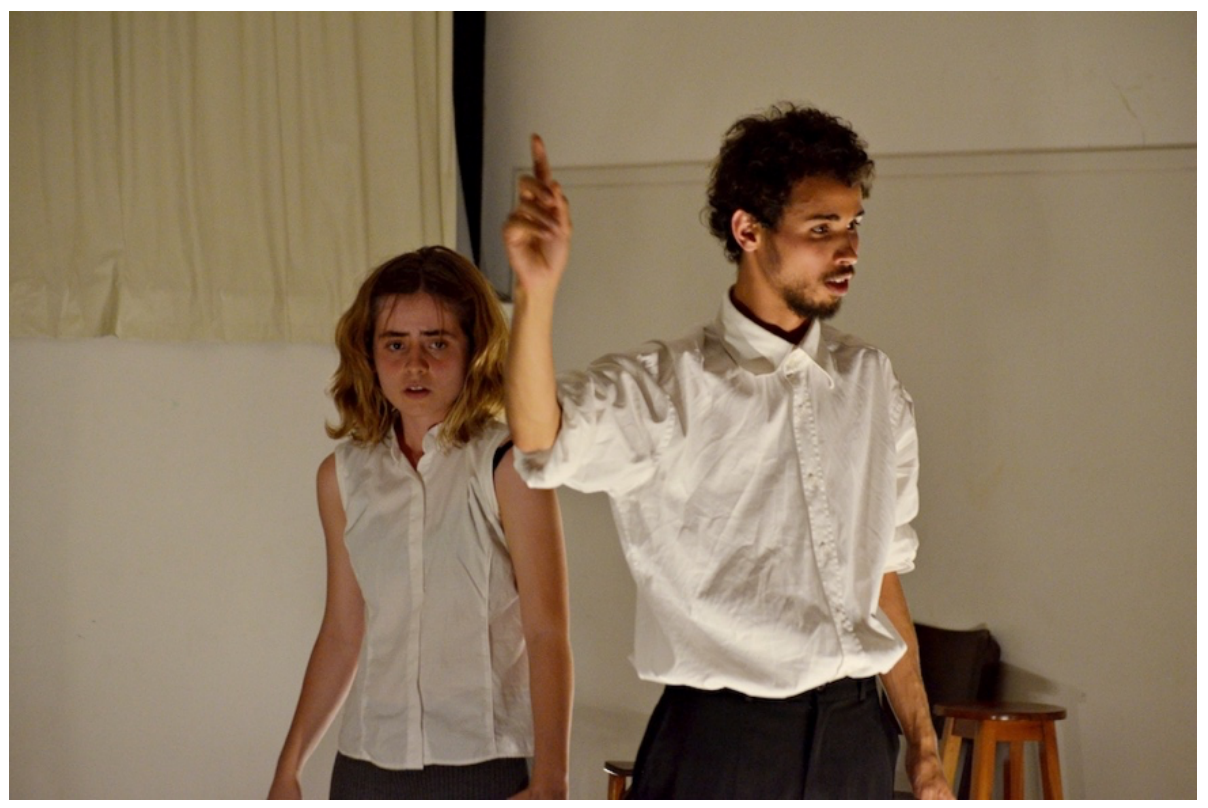

Foto: Gustavo Maia

Dessa forma, nas encenações das Cenas 3 e 7, o jogo estabelecido pelos atuantes, entre si e com o espaço, convidava os espectadores a ressignificar os textos pronunciados, resultando numa relação direta, evidente e explícita com o fascismo, muito embora a própria palavra "fascismo" não tenha sido mencionada sequer uma única vez nessas duas cenas. A dinâmica entre texto e ações, arquitetada pelos jogos, denotava uma espécie de perplexidade diante de uma situação incompreensível, incognoscível, porque irracional, como se ambas as cenas estivessem transpassadas, o tempo todo, por um mesmo misto de pergunta e espanto: "Como foi possível?! Como é possível!?” 


\title{
Um "grande homem comum", sem graça e sem amor
}

Outro fenômeno, especialmente importante para algumas cenas do espetáculo, e que, associado à solidão e massificação, também caracteriza o fascismo, foi a questão do líder totalitário e o modo como sua autoridade é construída. Em relação a esse assunto, os trabalhos voltados à área da psicologia, ou que se apoiam manifestamente nessa fonte, tiveram peso acentuado nas pesquisas para a encenação.

Wilhelm Reich, em seu famoso Psicologia de massas do fascismo, entende que há relações diretas entre o surgimento das massas fascistas e a educação familiar patriarcal tradicional das classes médias baixas (sic) nas sociedades industrializadas. Para ele, o führer estabelece uma ligação sentimental pessoal com as massas, invocando uma figura paterna ideal e idealizada, ao mesmo tempo atencioso e rígido, protetor e autoritário em relação ao grupo que o segue, e que reforça elementos da estrutura psicológica profunda dos indivíduos. Segundo Reich (2001, p. 57),

\begin{abstract}
Se ele [o führer] souber como despertar os laços afetivos da família, nos indivíduos das massas, ele será também uma figura do pai autoritário. Ele atrai todas as atitudes emocionais que foram num dado momento devidas ao pai, severo mas também protetor e poderoso (poderoso na visão da criança) [...]. Quanto mais desamparado o indivíduo de massas se tornou, em consequência da sua educação, mais acentuada é a sua identificação com o führer, isto é, mais a necessidade infantil de proteção é disfarçada sob a forma de um sentimento em relação ao führer.
\end{abstract}

Já o filósofo e sociólogo Theodor Adorno, no artigo $A$ teoria freudiana e o padrão da propaganda fascista, aponta o mesmo mecanismo de identificação com o "todo-poderoso e ameaçador pai primitivo" (Adorno, 2006, p. 172) de que fala Reich, recorrendo, por seu turno, aos estudos de Sigmund Freud. Trata-se de um processo em que indivíduos-massa-solitários abrem mão de seu próprio "eu", substituindo-o por um mesmo objeto, o líder, que desempenha o papel de "pai primordial", de soberano infalível. Mas Adorno ainda enfatiza que, para que desperte sentimentos intensos nas massas, o líder fascista precisa, ele mesmo, 
desprender-se de sentimentalismos, precisa ser a encarnação do rigor e autoridade irrestrita que a massa procura. Nos termos de Adorno, "o líder só pode ser amado se ele próprio não amar" (Adorno, 2006, p. 176). Por tanto, o líder especificamente fascista é aquele que joga fora seus sentimentos mais delicados para se tornar a figura pétrea a que as massas possam identificar como pai severo. Assim, Adorno menciona que,

Parece significativo que na sociedade atual, com suas massas fascistas artificialmente integradas, a referência ao amor esteja quase completamente excluída. Hitler afastou-se do papel tradicional do pai amoroso e substituiu-o inteiramente pelo papel negativo da autoridade ameaçadora. O conceito de amor foi relegado à noção abstrata de Alemanha. (Adorno, 2006, p. 170 e 171).

Na peça Acima de tudo, esse mecanismo de identificação das massas com um líder fascista foi abordado em especial na Cena 5, A extraordinária história do palhaço de uma única piada. Nela, é apresentada ao público a figura de Zobo, um palhaço sem graça e que só conta, em seu limitadíssimo repertório, com uma única piada, que ele repete à exaustão. Frustrado e cansado, ao perceber que sua audiência sentia mais pena e constrangimento do que graça de sua piada única, Zobo resolve se livrar de seus sentimentos, visando alcançar uma carreira de sucesso. Na dramaturgia, esse momento é descrito do seguinte modo:

Sentado na privada do banheiro de sua casa, em um dia de intensa diarreia, Zobo chorou copiosamente, cheio de pena, compaixão, piedade e uma lasca de nojo de si mesmo! Era uma imagem triste, aquela, vocês podem imaginar. Depois de secar suas lágrimas, Zobo deu descarga em todos esses sentimentos, junto de sua cagada descomunal! E passou a ser um palhaço incapaz de sentir pena, de sentir compaixão, de sentir piedade por qualquer pessoa, e ficou só mesmo com seu cotoco de nojo entalado na garganta. (Valença, 2020, p. 62).

No universo da peça, essa tomada de decisão de Zobo marca a virada de sua trajetória rumo ao estrelato. Para assumir a postura de uma celebridade rigorosa, capaz de desempenhar o papel de dirigir sua audiência, Zobo abre mão de seus próprios sentimentos e torna-se um "grande homem”, que não ama e que é "grande" justamente por não amar. A personagem Zobo torna-se, então, uma 
grande atração, atingindo uma multidão de pessoas que, exatamente como ele, "esperavam diante de suas pequenas telas ${ }^{10}$ pelo sinal certo para disparar um riso forçado diante de sua piada única!" (Valença, 2020, p. 63).

A Cena 5 retrata ainda outra característica do mecanismo de identificação fascista, subentendida em Reich mas apontada explicitamente por Adorno: o reconhecimento do líder como um igual, como um indivíduo que age e se mostra exatamente como qualquer outro, e não como alguém mais capacitado ou que se preparou para governar uma nação. É exatamente o fato de ser sem graça que propicia com que o palhaço Zobo torne-se o objeto de identificação por parte da multidão; sua frustração, solidão e medianidade o fazem ser igual a todo mundo e a qualquer um. Esse é o mecanismo psicológico, segundo Adorno, que une o führer e a massa fascista: ele é superior porque a massa o identifica como um igual e os indivíduos que compõem a massa identificam-se entre si por meio dessa identificação coletiva com o líder comum. "Haviam tantas, tantas pessoas solitárias, sozinhas e misantropas, tal como Zobo, dispostas a um riso forçado de piada única sem graça" (Valença, p. 64 e 65), como reforça outro trecho da cena.

O líder fascista não é nenhum gênio extraordinário, uma pessoa dotada de virtudes excepcionais, mas uma espécie de "grande homem comum”, que só é alçado à grandeza por uma massa de indivíduos que se identifica com a banalidade e insignificância de sua liderança. Charles Chaplin já havia denunciado isso em um de seus mais famosos filmes, irônica e significativamente intitulado "O Grande Ditador", não por acaso uma das referências para a Cena 5. Talvez igualmente inspirado pelo filme de Chaplin, Adorno afirma que:

um dos dispositivos básicos da propaganda fascista personalizada é o conceito do "grande homem comum" (great little man), alguém que sugere tanto onipotência quanto a ideia de que é apenas um de nós, um americano simples, saudável, não conspurcado por riqueza material ou espiritual. A ambivalência psicológica ajuda um milagre social a se realizar. A imagem do líder satisfaz o duplo desejo do seguidor de se submeter à autoridade e de ser ele próprio a autoridade [...]. As pessoas que obedecem aos ditadores sentem que eles são supérfluos. Elas se reconciliam com essa contradição por meio da presunção de que elas próprias são o opressor cruel. (Adorno, 2006, p. 177).

${ }^{10}$ Como acontece ao longo de toda a peça, também a Cena 5 está repleta de referências ao uso dos celulares. 
Assim, a Cena 5 é a que mais diretamente busca abordar a identificação entre as massas solitárias e seu líder banal e ordinário, um dos mais recorrentes assuntos quando se discute o fenômeno do fascismo. Mas é um tema também abordado na Cena 6, dessa vez associado à dimensão econômica e social que viabiliza a ascensão do führer.

\section{Tempos análogos}

A Cena 6, As razões de um taxista, talvez seja a que estabelece paralelos mais diretos entre o período em que o fascismo primeiramente existiu e seu ressurgimento atual. As correspondências foram abordadas tanto na dramaturgia quanto na encenação, em que a dinâmica de cena, novamente criada a partir de jogo teatral, sugere ressignificações do texto.

A primeira relação direta foi construída pela transição entre a Cena 5 e a 6, ao modo de uma montagem cinematográfica, em que o sentido de uma sequência emerge do modo como cenas diferentes são colocadas em perspectiva. A Cena 5 termina com o hino nacional brasileiro sendo executado em comemoração a Zobo ter se tornado o maior palhaço da história do Brasil. A rubrica da cena indica que "todos cantam a primeira parte do hino a plenos pulmões. Imediatamente após a palavra 'Brasil', blackout com uma projeção ao fundo indicando: ALEMANHA, década de 1930" (Valença, 2020, p. 66). O encadeamento colocava o hino nacional brasileiro, interrompido abruptamente no grito de "Brasil", em uma espécie de antítese com a projeção da frase "ALEMANHA, década de 1930", permitindo que os espectadores, jogados bruscamente de um período histórico a outro, gerassem suas próprias sínteses a partir desse dispositivo dialético de transição.

A sequência da cena dá continuidade ao paralelismo destacando a dimensão econômica e social que favorece o surgimento do fascismo. Ela descreve a seguinte circunstância: na sede de uma empresa de taxis na Berlin dos anos 1930, três taxistas conversam, enquanto ouvem rádio e esperam por alguma corrida.

Como se sabe, a chamada "crise de 1929" inicia um ciclo de recessão em todo 
o mundo, resultando numa situação econômica catastrófica na Alemanha, com levantamentos que dão conta do número de 6 milhões de desempregados em 1933 (ano em que o partido nazista assume o governo), significando um terço dos trabalhadores (Feijó, 2009, p 246). Por seu turno, o Brasil de 2018 (ano em que realizamos a pesquisa para a encenação) apresentava cerca de 12,2 milhões de desempregados, ou $11,6 \%$ do contingente da força de trabalho, índice que variou pouco desde 2017, quando atingiu 12\% (IBGE, 2018). Assim, a cena trava alguns diálogos que tematizam essa questão, como o que podemos observar abaixo:

TAXISTA 1 - Sério... a gente tem que dirigir com duas vezes mais atenção atualmente. Como cresceu a quantidade de gente nas ruas! Pra que tanta gente na rua? Será que eles não têm nada que fazer?

TAXISTA 3 - É o desemprego. Eles não têm nada o que fazer mesmo! (Valença, 2020, p. 68).

Como consequência do desemprego, observa-se um crescimento acentuado do trabalho informal e do subemprego, onde imperam relações trabalhistas sem nenhum tipo de garantias sociais; processo que ficou conhecido no Brasil como "uberização", em referência à conhecida multinacional norte-americana de transporte privado que funciona através de um aplicativo de celular ${ }^{11}$. Foi justamente essa conexão, entre condições precárias de emprego no Brasil e o modelo de trabalho configurado pela UBER, que nos fez escolher uma companhia de taxis de Berlin nos anos 1930 como situação para a Cena 6.

Essas relações empregatícias, aqui e atualmente como na Alemanha dos anos 1930, estabelecem um trabalho objetificante - porque transforma o ser humano em estatística - e alienante - já que impede a percepção da própria situação e dos mecanismos e interesses econômicos e políticos que o levaram a esse estado. Essa alienação foi tematizada na cena através do depoimento de um dos personagens que atribui a "culpa" de sua situação à corrupção de uma classe política despersonalizada e genérica:

${ }^{11}$ Ver, entre outros exemplos possíveis: Ricardo Antunes. O privilégio da servidão. São Paulo: Boitempo, 2018. Este também fez parte dos livros consultados em nosso processo de pesquisa para a montagem de Acima de tudo. 
TAXISTA 1 - Maus políticos? São tudo uma corja de corruptos, isso sim. Olha pra mim! Eu dei um duro danado pra conseguir as coisas. Estudei, me esforcei... Pelo meu trabalho pessoal, tinha conseguido juntar um dinheiro, morar e comer bem, ter uma dignidade. Pelos meus próprios méritos, compreende? Eu perdi tudo, tudo. Eu e muitos dos meus amigos, que estão todos desempregados, eu ainda tenho sorte de estar aqui! Sempre fiz tudo direito, nunca fiz nada errado, e quem acaba ficando com o bolso cheio são esses políticos. Olha, eu fico muito puto que eu tenha perdido meu futuro por causa de uns bandidos. Bandidos de gravata, mas bandidos do mesmo jeito. (Valença, 2020, p. 74).

Esse trecho é uma adaptação de algumas entrevistas realizadas pelo sociólogo Jessé Souza, entre 2016 e 2018, e publicadas em A classe média no espelho. Na fala desse personagem, tentamos condensar vários dos elementos que, segundo Jessé, caracterizam a classe média brasileira. Estão presentes aí o individualismo, a meritocracia, o medo da proletarização e, em especial, a falta de entendimento dos fatores que levam ao empobrecimento e que resultam num ódio à política. Para Jessé, "na manipulação fascista e neofascista dos setores da massa da classe média, o aspecto decisivo é sempre o terror despertado pela possibilidade de desclassificação social." (Souza, 2018, p. 133).

A combinação de medo e agressividade são fatores que favorecem o surgimento de figuras autoritárias, supostamente descoladas da política tradicional, e que aglutinam as esperanças e a identificação de parcelas massivas da população. Assim, tal qual na cena anterior, em que o palhaço Zobo assume o lugar de um líder, a Cena 6 também finaliza com a identificação de um führer capaz de guiar seu povo:

TAXISTA 1 - Não se deixe enganar! A Alemanha precisa ser refeita por inteira! Aqui todo mundo só pensa em roubar e tirar vantagem. Nenhum país avança desse jeito, nenhum... é preciso botar as coisas nos lugares, pôr ordem nesse país, custe o que custar!

TAXISTA 2 - Pronto... consegui! (o rádio começa a transmitir um discurso de Hitler)

TAXISTA 1 - Ó, ó, ó... Aumenta aí! Esse sim! Não tem papas na língua, tem coragem de dizer o que está acontecendo cara a cara, doa a quem doer! $[\ldots]$

TAXISTA 3 - E não é um político? 
TAXISTA 1 - Claro que não! É gente como a gente, nunca teve envolvido em escândalo, corrupção. Esse sim vai dar uma limpa nessa situação toda que está aí! [...] Presta atenção no que estou te dizendo! Se esse cara fizer o que está prometendo, a Alemanha volta a ser potência, rapidinho! Ele só precisa de apoio nosso, pra moralizar isso tudo que está aí. Grava o que estou te falando: dentro de mais ou menos um século, ele vai ser reconhecido como um verdadeiro mito! (Sai da sala). (Valença, 2020, p. 77 e 78).

Desse modo, a Cena 6 constrói paralelos entre o fascismo dos anos 1930 e o neofascismo atual através de dois mecanismos: estrutural, em razão do lugar que ocupa na sequência de cenas - a cena imediatamente anterior ressignifica e tensiona toda a Cena 6 , desde a transição abrupta ao resultado similar de surgimento de um líder totalitário; e temático, abordando a similaridade entre a situação econômica e social na Alemanha pré-nazista e no Brasil atual. Porém, a encenação desse trecho ainda apresentou um terceiro mecanismo que também estabelecia paralelos entre o nazismo e o neofascismo, e que nos leva, novamente, ao universo tecnológico.

\section{As peças devem se encaixar de algum modo}

Como no restante da encenação, o jogo realizado na Cena 6 também propôs ressignificações do texto dramatúrgico. A rubrica mencionava que um dos taxistas estaria tentando sintonizar um rádio e que, ao conseguir fazê-lo, soaria a transmissão de um discurso de Hitler. Ao invés de um aparelho cenográfico, que seria uma escolha mais coerente com o realismo do trecho, no processo de jogos optamos pelo uso de um celular conectado a uma caixa de som, manuseados de forma explícita frente ao público, deixando a remissão à década de 1930 exclusivamente por conta do diálogo e da interação entre os personagens. Dessa forma, o público assistia aos atores manipulando um celular, mas referindo-se a ele como um rádio; via um aparelho (pós-moderno) de tecnologia de ponta servindo como referente de um aparelho de tecnologia antiga.

O jogo, assim proposto, estabelecia um paralelo evidente entre o rádio na Alemanha de 1930 e o celular no Brasil atual, ambos, veículos de massificação, de 
solidão e de forjamento de "unidade nacional". A mesma solidão do homemmassa alemão de 1930 diante do rádio, capaz de fabricar gigantescas manifestações em defesa do nazismo, foi produzida no homem aparelhado do Brasil atual, diante de suas telas individuais de celulares, desembocando igualmente em enormes manifestações de rua pautadas por reivindicações de políticas autoritárias. É fato reconhecido que o rádio foi um dos principais meios de divulgação das ideias nazistas e representou, para a Alemanha da década de 1930, o mesmo potencial de massificação que as mensagens de aplicativos de celular tiveram recentemente no Brasil. Conforme a análise/testemunho de Adorno e Horkheimer (1985, p. 132), o rádio

\begin{abstract}
assume a forma de uma autoridade desinteressada, acima dos partidos, que é como que talhada sob medida para o fascismo. O rádio torna-se aí a voz universal do Führer [...]. O carisma metafísico do Führer, inventado pela sociologia da religião, acabou por se revelar como a simples onipresença de seus discursos radiofônicos [...]. O fato gigantesco de que o discurso penetra em toda parte substitui seu conteúdo [...]. Nenhum ouvinte consegue mais apreender seu verdadeiro sentido, enquanto o discurso do Führer é, de qualquer modo, a mentira. Colocar a palavra humana como algo de absoluto, como um falso imperativo, é a tendência imanente do rádio. A recomendação transforma-se em um comando.
\end{abstract}

Substitua-se, nestes trechos, a palavra "rádio" por "WhatsApp" ou "celular" e teremos uma descrição quase exata do fenômeno que ocorreu no Brasil recente. Para retratar esse paralelo, o aparelho síntese rádio/celular ocupava papel central na encenação do trecho em questão. Durante toda a cena, o taxista que tentava sintonizar o rádio/celular retirava peças de dentro dele, no intuito de consertar o aparelho, e fazia intervenções pontuais na conversa entre os outros dois taxistas, sempre fazendo referência ao rádio/celular. O exemplo mais marcante disso encontra-se na seguinte sequência do texto:

TAXISTA 3: É... é... Você tem razão! A vida é assim. De um lado, tantos desempregados pelas ruas...

TAXISTA1: ... de outro, grandes perspectivas!

TAXISTA 2: Essas duas peças devem se encaixar de alguma maneira, só não consigo entender como! (Valença, 2020, p. 76). 
A fala do Taxista 2, nesse trecho, era dada com o ator exibindo ao público dois celulares e referindo-se a eles como peças internas do rádio que ele tentava consertar.

Assim, enquanto o texto da cena tematizava o nazismo como fruto de uma trajetória de decadência econômica e social das classes médias alienadas, o jogo entre atores e com objetos ressignificava a dramaturgia, remetendo novamente ao universo brasileiro atual. A síntese rádio/celular proposta pelo jogo estabelecia uma espécie de sobreposição de temporalidades, de superposição histórica que gerava estranhamento, possibilitando refletir sobre os aparelhos que propagaram os discursos autoritários na Alemanha da década 1930 e no Brasil da segunda metade da década de 2010. Trata-se da comparação entre o fascismo e o neofascismo, a proposta original da encenação, concretizada por meio de um jogo.

O processo de criação da peça Acima de tudo - teatro antifascista exemplifica a metodologia que vem sendo adotada dentro da pesquisa em andamento na UFOP já há alguns anos, em que sociologia, filosofia e história desempenham papel preponderante na preparação teórica do espetáculo e na construção dramatúrgica, enquanto jogos teatrais são empregados para ressignificarem os textos. Tal metodologia não foi exatamente planejada, antes foi se consolidando experimentalmente no decorrer da pesquisa e atingiu, com Acima de tudo, uma versão mais bem depurada.

O que a peça buscou retratar foi essa sequência de condições e eventos interligados: generalização do uso do celular, hiper conectividade e acessibilidade, massificação, solidão, fascismo. Numa linguagem mais flusseana, meta-aparelhos que funcionam em cascata, ou em série, com aparelhos despejando demandas para dentro de outros aparelhos através de outputs e inputs em relação envelopante. Na atual situação em que nos encontramos, nada pode ser mais importante do que parar esse funcionamento automático do aparelho fascista, um aparelho que se nutre da solidão, da desesperança, da pulsão de morte. Certamente, não é um trabalho exclusivo do teatro, mas de todas e todos que 
defendem a democracia e a vida. Mas, se há ainda algo de humano no campo da representação, é em resistência ao fascismo que o teatro deve se guiar.

\section{Referências}

ADORNO, Theodor W. A teoria freudiana e o padrão da propaganda fascista. Margem Esquerda: ensaios marxistas, no 07 (p. 164-189). São Paulo: Boitempo Editorial, 2006.

ADORNO, Theodor W.; HORKHEIMER, Max. Dialética do esclarecimento. Rio de Janeiro: Zahar, 1985.

ARENDT, Hannah. Origens do totalitarismo. São Paulo: Companhia das Letras, 1989.

BAUMAN, Zygmunt. 44 cartas do mundo líquido-moderno. Rio de Janeiro: Zahar, 2011.

BROOK, Peter. O ponto de mudança: quarenta anos de experiências teatrais 19461987. Rio de Janeiro: Civilização Brasileira, 1995.

DOMINGOS, Clóvis. É possível organizar poeticamente o pessimismo? Horizonte da Cena, Belo Horizonte, 21 de agosto de 2019. Disponível em https://www.horizontedacena.com/e-possivel\%AD-organizar-poeticamente-opessimismo/. Acesso em: 22 ago. 2019.

FEIJÓ, Ricardo Luis Chaves. Uma interpretação do primeiro milagre econômico alemão (1933 - 1944). Revista de Economia Política, vol. 29, no 2, pp. 245-266, abriljunho/2009. Disponível em: https://www.scielo.br/pdf/rep/v29n2/05.pdf Acesso em: 06 maio 2019.

FLUSSER, Vilém. O universo das imagens técnicas. São Paulo: Annablume, 2008.

FLUSSER, Vilém. Pós-História: vinte instantâneos e um modo de usar. São Paulo: Annablume, 2011.

FLUSSER, Vilém. O último juízo: gerações II. São Paulo: É Realizações, 2017.

HAN, Byung-Chul. Sociedade do cansaço. Petrópolis, RJ: Vozes, 2017.

IBGE. Pesquisa nacional por amostragem de domicilios contínua: PNAD. Indicadores mensais produzidos com informações do trimestre móvel terminado em novembro de 2018. Rio de Janeiro: IBGE, 28 de dezembro de 2018. Disponível em:

https://agenciadenoticias.ibge.gov.br/media/com mediaibge/arquivos/25a1c96652 
1f8822cdc441fdbc75f49c.pdf Acesso em: 06 maio 2019

IBOPE. (2013). 89\% dos manifestantes não se sentem representados por partidos. Disponível em: http://www.ibopeinteligencia.com/noticias-e-pesquisas/89-dosmanifestantes-nao-se-sentem-representados-por-partidos/. Acesso em: 10 jul. 2019.

MARCUSE, Herbert. Estado e indivíduo sob o nacional-socialismo. In: Tecnologia, Guerra e Fascismo. São Paulo: Fundação Editora da UNESP, 1999.

REICH, Wilhelm. Psicologia de massas do fascismo. São Paulo: Martins Fontes, 2001.

SOUZA, Jessé. A classe média no espelho. Rio de Janeiro: Estação Brasil, 2018.

VALENÇA, Ernesto. Acima de tudo - teatro antifascista. Rio de Janeiro: Autografia, 2020.

Recebido em: 12/06/2020

Aprovado em: 05/10/2020 